\title{
Production potential and economics of mustard under different cropping sequences with reference to integrated nutrient management
}

\author{
R.P.S. Tomar \\ Krishi Vigyan Kendra (RVSKVV), Gwalior (M.P.) India \\ (Email: rpstomar2007@ rediffmail.com)
}

\begin{abstract}
The experiment was conducted during Rabi season of 1999-2000 and 2000-01 on sandy loam soil at JNKVV, College of Agriculture, Farm, Gwalior (M.P.) to study the effect of different cropping systems and fertility levels on yield, yield attributes and economics of mustard (var. Pusa bold). Results showed that the maximum seed yield ( $\left.23.05 \mathrm{q} \mathrm{ha}^{-1}\right)$, oil content (40.39\%), net return (Rs. $23661 \mathrm{ha}^{-1}$ ), energy output (74024 MJ ha-1) and B:C ratio (3.19) were observed in blackgram - mustard followed by Peral milletmustard cropping system. Fertilizer application of $50 \%$ RD + Azotobacter + PSB @ $20 \mathrm{~g} \mathrm{~kg}^{-1}$ seed, resulted in maximum net return (Rs. $20797 \mathrm{ha}^{-1}$ ) and B.C. ratio (2.99) as compared to higher application of fertilizers.
\end{abstract}

Key Words : Cropping sequences, INM, Economic, Energy input output, Yield

View Point Article : Tomar, R.P.S. (2020). Production potential and economics of mustard under different cropping sequences with reference to integrated nutrient management. Internat. J. agric. Sci., 16 (2) : 184-186, DOI:10.15740/HAS/IJAS/16.2/184-186. Copyright@ 2020: Hind Agri-Horticultural Society.

Article History : Received : 02.03.2020; Revised : 04.05.2020; Accepted : 09.05.2020 